DOI: 10.22591/magyurol.2018.1.magyara.17

\title{
Tíz kilogrammos scrotalis elephantiasis mútéti megoldása
}

\author{
Magyar András dr., Póth Sándor dr., Köves Béla dr., Tenke Péter dr.
}

Jahn Ferenc Dél-pesti Kórház és Rendelőintézet, Urológiai Osztály, Budapest (osztályvezető: Tenke Péter dr.)

\author{
Levelezési cím: \\ Dr. Magyar András \\ 1076. Budapest, \\ Thököly út 21. III/28. \\ E-mail: magyara@gmail.com \\ Tel.: +36 31/7839686
}

\begin{abstract}
ÖSSZEFOGLALÁS
Bevezetés: A szubtrópusi övezetben endémiás filariasis okozta scrotalis elephantiasis, avagy scrotalis lymphoedema hazánkban elvétve fordul elő. Európában a leggyakrabban a scrotum egyéb okból adódó nyirokelvezetési zavara áll a betegség hátterében. Egy rendkívül nagyméretű scrotalis lymphoedema szakszerū kivizsgálását és sebészeti ellátását kivánjuk bemutatni.
\end{abstract}

Esetismertetés: 66 éves páciensünk nem járt külfö|dön, lymphoedema miatt korábban már átesett hasi rekonstrukción. A labor- és ultrahangvizsgálatokon kívül szövettani mintavétel is történt, amely scrotalis lymphoedemát igazolt, gyulladás és daganat jelei nélkül. Plasztikai sebészeti konzíliumot követően a nagyméretű elváltozás sebészeti reszekcióját és a scrotum plasztikai rekonstrukcióját végeztük. A páciens sebe szövődménymentesen gyógyult, a mütéti kezeléssel a páciens jelentős életminőségbeli javulását értük el.

Következtetések: A kivizsgálás fontos eleme az alapos anamnézisfelvétel, illetve a páciens esetleges, endémiás területre történő külföldi utazásának kiderítése. Ezen kívül fontos a malignitás kizárása, amelynek érdekében szükségessé válhat a szöveti mintavétel. A műtéti megoldás során plasztikai sebészeti ismeretek szükségesek.

\section{KULCSSZAVAK}

ELEPHANTIASIS, LYMPHOEDEMA, SCROTUM, SEBÉSZI KEZELÉS

\section{Bevezetés}

A scrotalis lymphoedema, másnéven scrotalis elephantiasis hazánkban ritkán előforduló krónikus állapot, amely a herezacskó masszív megnagyobbodásával jár. A betegség leggyakrabban a trópusi és szubtrópusi övezetben fordul elő, ahol hátterében endémiás filariasis okozta nyirokút-obstrukció áll, amely a scrotum kötőszöveteinek jelentős hipertrófiáját, hiperpláziáját és folyadék-felhalmozását okozza (1).

\section{Surgical treatment of a huge scrotal elephantiasis}

\section{SUMMARY}

Objective: While in subtropical areas elephantiasis of the scrotum, or scrotal lymphedema is a common disease, caused by endemic filariasis, in Hungary, this condition is rarely seen. In Europe the most common cause of scrotal elephantiasis is the occlusion of lymphatic vessels secondary to other medical disorders. We wish to demonstrate the proper diagnostic workup and the surgical management of a giant scrotal lymphedema.

Case report: Our patient is 66 years old, has not been abroad recently and has already undergone an abdominal reconstruction due to lymphedema before. Following laboratory testing and ultrasound examination, a biopsy of the scrotum was performed, which did not prove the presence of any malignancy or inflammation. After counselling with a plastic surgeon, the enormous scrotal mass was surgically removed, followed by plastic reconstructive surgery of the scrotum. The wound healed without any complication and the patient has reported a significant improvement in his quality of life.

Conclusion: The physician should find out if the patient has travelled to an area where filariasis is endemic. To exclude malignancy, biopsy of the scrotum might be necessary. The reconstruction of the scrotum requires plastic surgical expertise.

\section{KEYWORDS}

ELEPHANTIASIS, LYMPHEDEMA, SCROTUM, SURGICAL TREATMENT

Nyirokúti filariasis 120 millió embert érint világszerte, 40 millió betegnél okozva torzulást, vagy rokkantságot (2). Endémiás területeken a férfiak 50\%-ában eredményezhet scrotalis elváltozást (3).

Az elephantiasist Európában és más fejlettebb országokban általában egyéb eredetú nyirokút-elzáródás következtében kialakult nyirokkeringési zavar okozhatja, úgymint sebészeti nyirokcsomó-eltávolítás, sérülés, trauma, sugárkezelés, tumor, vagy infekció (lymphogranuloma venereum) (4-7). Hazánkban a scrotalis lymphedema incidenciája nehezen felbecsülhető, hi- 
szen Európában rendkívül ritkán fordul elő. Tanulmányozására korlátozott mennyiségű esettanulmány áll rendelkezésre. Esettanulmányunk során hatalmas méretű, térdig érő elephantiasis sikeres mútéti megoldását, posztoperatív sebkezelési stratégiáját kívánjuk szemléltetni. Páciensünk scrotuma 10 kg tömegúre növekedett, ami életminőségét jelentősen rontotta, járását, önellátását csaknem ellehetetlenítette.

\section{Esetismertetés}

\section{Anamnézis}

Hatvanhat éves, 135 kg-os páciensünk anamnézisében nem inzulin dependens diabetes mellitus (NIDDM), pitvarfibrilláció, 14 éve fennálló lymphoedema szerepel. Két évvel ezelőtt hasplasztikán esett át kötényhas miatt, ekkor 26 kg szövetet reszekáltak. A hasplasztikát követő két év alatt hatalmas méretü, térdig érő scrotalis lymphoedema fejlődött ki. A páciens nem járt külföldön, nem találtak nála infekciót, daganatos elváltozást, illetve onkológiai kezelésben sem részesült.

\section{Panaszok, tünetek és a megoldandó probléma}

Páciensünk masszív scrotalis megnagyobbodással jelentkezett ambulanciánkon. Az elváltozás jelentősen rontotta a páciens mobilitását, életminőségét, vizelési készségét és higiéniás önellátását, szociális életét, mindezek mellett nagy pszichés terhet jelentett számára. A mütét előtt készült fénykép az elváltozásról az 1. ábrán látható. A betegnek a mütétet megelőzően nem volt merevedési funkciója (Merevedés Minőségi Mutatója: 0 pont). A pácienst tájékoztattuk, hogy a mütét során a herék eltávolításra kerülhetnek, amit tudomásul vett és nem ragaszkodott a herék megtartásához.

\section{Diagnosztikai vizsgálatok eredményei}

Fizikális vizsgálata során nagymértékü obezitás és a térdig érő scrotális terime volt tapasztalható, ezeken kívül egyéb számottevő kóros eltérés nem igazolódott. A herék nem voltak tapinthatók és a hímvessző sem volt látható. A húgycsőnyilás mélyen a scrotumba volt ágyazódva, ennek ellenére katéter nélkül tudott vizelni, gyenge sugárban, a scrotum bőre és a fitymabőr által képződött csatornán keresztül. Laborvizsgálata, hasi-kismedencei ultrahang és hereultrahang vizsgálata daganatra, vagy infekcióra utaló kóros eltérést nem igazolt.

\section{Differenciáldiagnosztikai lépések, megfonto- lások, társszakmai konzíliumok}

A mütéti megoldást megelőzően elsősorban malignus daganat kizárása céljából a herezacskó biopsziáját végeztük (Bart biopty gun segítségével). A kórszövettani vizsgálat heges kötőszöveti átalakulást igazolt, ezen kívül egyéb kóros elváltozást nem mutatott. A mütéti

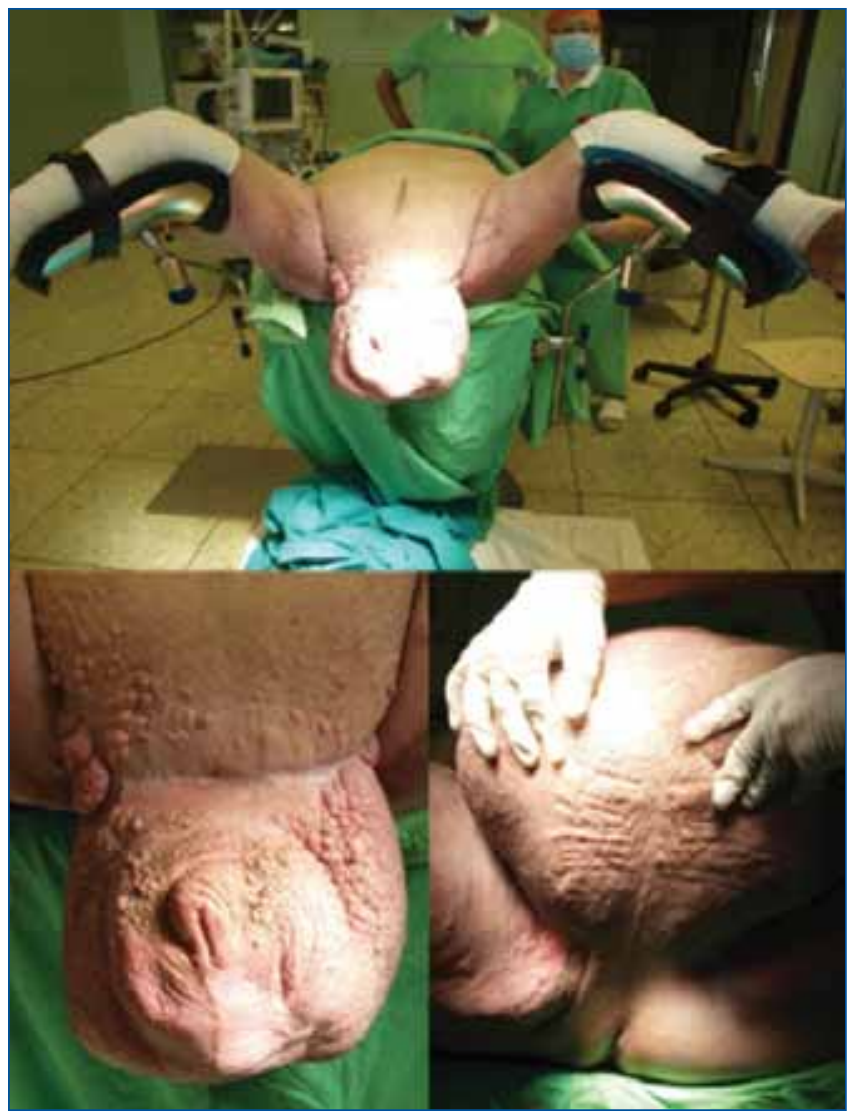

1. ÁBRA: Az ELVÁlTOZÁS A KEZELÉS ELŐTT

megoldás plasztikai sebészeti vonatkozásainak megbeszélésére plasztikai sebészeti konziliumot kértünk.

\section{Javasolt terápia, műtéti megoldás leírása}

A scrotalis elephantiasis legoptimálisabb kezelése az elváltozás sebészi eltávolítása (8). A terime reszekcióját és a scrotum rekonstrukcióját, konziliumot követően, plasztikai sebész jelenlétében végeztük. A beavatkozás során 10 kg szövetet reszekáltunk. A mütét során a heges környezetbe beágyazott atrofizált herék eltávolítása mellett döntöttünk. A péniszt börlebenyen keresztül a gátra ültettük ki. A sebet feszülésmentesen zártuk. A plasztikai sebész javaslatára a mütéti seb alsó sebzugában körülbelül $5 \mathrm{~cm}$-es nyílást hagytunk, amelyre speciális vákuum-szívó drén rendszert csatlakoztattunk. Az eszköz egy a sebbe helyezett szivacsból és egy hozzá csatlakoztatott elektronikus szívóberendezésből áll. A vákuum asszisztált sebkezelés közismert és népszerü plasztikai sebészeti eljárás, amely égési sebek és többek között lymphoedemás bőrelváltozások rekonstrukciója során alkalmaznak (9). Az elektronikus rendszer által generált vákuum jelentősen felgyorsítja a sebgyógyulást, mivel a váladékok folyamatos eltávolítását biztositja, emellett javitja a szövetek regenerációs képességét. A posztoperatív szak eseménytelenül zajlott, a sebváladékozás fokozatosan megszünt, a vákuum-szívó drén 


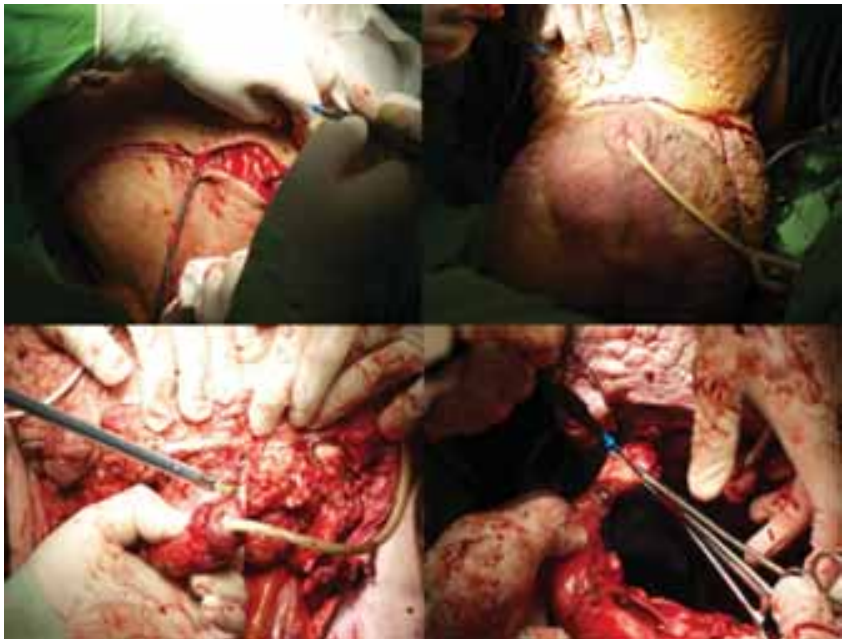

2. Ábra: A kóros elváltozÁs határainak bemetszéSE (GÁTTÁJÉKON, ILLETVE AZ OS PUBIS FELETT), BŐRLEBENY-KÉPZÉS, MAJD A PÉNISZ ÉS A HERÉK KIPREPARÁLÁSA, A KÓROS SZÖVETEK ÉS A HERÉK ELTÁVOLÍTÁSA

rendszert 4 nap után eltávolítottuk, sebe fokozatosan begyógyult. A végleges kórszövettani vizsgálat malignitást nem igazolt. A mütéti megoldás lépéseit a 2-4. ábrákon szemléltetjük. A páciens később az életminőségében tapasztalt jelentős javulásról számolt be és lehetővé vált számára a rendszeres testmozgás. A 4. ábrán szemléltetjük a gyógyult állapotot, a mütét után három héttel. Urológiai sebészeti ambulanciánkon három héten keresztül történt a nyomonkövetés, amely során sebe maratéktalanul begyógyult, további rekonstrukcióra nem volt szükség. Három héten túl történő kontrollja, további gondozása, tesztoszteronszint beállitása a lakhelyén illetékes urológiai szakrendelésen zajlott.

\section{Megbeszélés}

A scrotalis lymphoedemának számos oka ismert, amelyek közül a leggyakoribb a trópusi-szubtrópusi övezetben honos filariasis, míg a fejlettebb országokban legtöbbször sebészeti nyirokcsomó-eltávolítás, sérülés, trauma, sugárkezelés, tumor, vagy infekció okozta másodlagos nyirokút-elzáródás áll a betegség hátterében. Európában a scrotalis elephantiasist igen ritka betegségként tartják számon. Elófordulása az Amerikai Egyesült Államokban növekvő tendenciát mutat (9). A mútéti megoldásnak két alapvető módja ismert:

1. a nyirokutak helyreállitása,

2. a nyirokutak, illetve nyirokszövet eltávolítása.

A nyirokutak helyreálítási módjának kidolgozására a történelem során többféle próbálkozás történt, ezüst, fém, vagy múanyagcsövek beültetésével (10). A nyirokutak helyreállítását ma a nyirokutak anasztomózisa, vagy nyirokér-véna anasztomózis képzése útján végzik. Kisfokú, kimutatható nyirokút-elzáródás esetén alkalmazható ez az eljárás még a hegesedés megjelenése előtt (8).

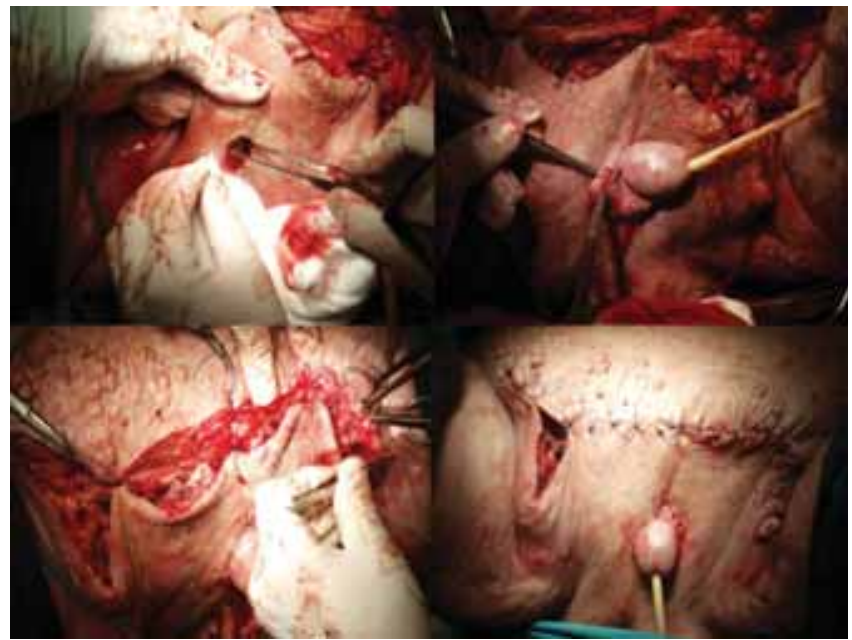

3. Ábra: Pénisz-rekonstrukció, tehermentesítő öltéSEK ÉS A SCROTUM REKONSTRUKCIÓJA

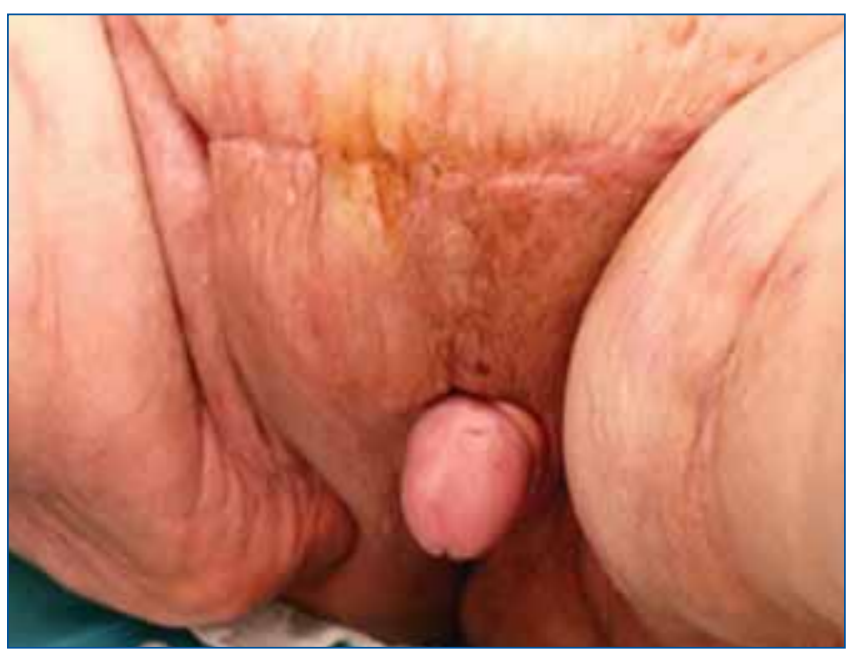

4. Ábra: HÁrom hétTel a mütét utÁN

Az 1950-es években történtek próbálkozások a scrotum combhoz történő rögzítésével, ami nem jelentett definitív megoldást. Később a kóros többletszövetek eltávolítására és a scrotum rekonstrukciójára számos technikai megoldás született (1). A legjobb eredményeket, a scrotalis lebenyekkel történő plasztikai rekonstrukcióval érhetjük el (11). Mediális comblebenyek szintén sikeresen alkalmazhatók, amennyiben nincs elegendó ép scrotumbőr. A mesh graft plasztika pedig széles körben elfogadott eljárás a péniszbőr-defektusok fedéséhez. Az egyik legnagyobb vizsgálat egy 350 esetet bemutató esettanulmány, amely filariasis okozta scrotalis elephantiasis sebészi eltávolításának eredményességét vizsgálja. A péniszbőr rekonstrukcióját félvastag bőrgraftok segítségével végezték. A scrotumot elcsúsztatott bőrlebenyek segítségével állitották helyre (1). Általános szövődményarányuk 19,4\% volt. Fertőzés 10,2\%-ban, haematoma 8,2\%-ban, míg recidíva 7,3\%os arányban jelentkezett, amelyet a szerzők a filariasis elleni gyógyszerek elhagyásával magyaráztak. 
Egy másik vizsgálat 70 páciens esetét mutatja be, ahol scrotumbőr rekonstrukcióját félvastag bőrgraft segítségével végezték. A nyomonkövetés 0,5-6 évig történt. A scrotum eltávolítását követően a határos bőrterületeket használták a rekonstrukcióhoz. A hímvessző bőrének rekonstrukcióját félvastag bőrgraftok segítségével oldották meg, amellyel véleményük szerint jobb taktilis és erekciós eredmények érhetők el, mint lebenyképzéssel. A mütéttel az életminőség, penetrációképesség és a szexuális elégedettség javulását érték el a betegeknél, és csupán egy esetben volt szükség ismételt mútétre, 2 év után jelentkező recidíva miatt (6).

Páciensünk kivizsgálása során a betegségének egyértelmú, bizonyítható oka nem igazolódott. Extrém túlsúlya szerepet játszhatott a lymphoedema kialakulásában. Ismert, hogy a túlsúlyos betegek bőr alatti szöveteiben nagyobb mennyiségben található intersticiális folyadék és nagyobb a szövetek nyiroku- takra gyakorolt nyomása. A kialakult nyirokpangást fokozza a testmozgás hiánya. A nyirokkeringés zavara kifejezettebben érvényesül a lógó testtájakon (12, 13). Elképzelhető, hogy az anamnézisében szereplő kötényhasat is részben nyirokkeringési zavar okozhatta, amelynek sebészeti megoldását követően fejődött ki a lymphoedema a scrotumban.

A scrotalis elephantiasis mútéti rekonstrukciója során törekednünk kell a herék megóvására, amikor elegendő bőrmennyiség áll rendelkezésre a scrotum-rekonstrukcióhoz. Betegünknél a kiterjedt heges környezetben lévő herék atrófiás jellege miatt a herék eltávolítása mellett döntöttünk. Extrém méretú elephantiasis mútéti megoldása komoly kihívást jelenthet, kiemelten fontos a plasztikai mútétekben, bőrlebenyképzésben való jártasság. Megfelelő technikával és posztoperatív sebkezeléssel jó eredmények érhetők el.

\section{Irodalom}

1. Dandapat MC, Mohapatro SK, Patro SK. Elephantiasis of the penis and scrotum. A review of 350 cases. American journal of surgery. 1985; 149(5): 686-90. https://doi.org/10.1016/50002-9610(85)80156-2

2. http:/www.who.int/mediacentre/factsheets/fs $102 / \mathrm{en} /$. WHO website. 2018.01.26.

3. https://www.cartercenter.org. The Carter Center "Lymphatic Filariasis Elimination Program". 2008-07-20.

4. McDougal WS. Lymphedema of the external genitalia. The Journal of urology. 2003; 170(3): 711-6. https://doi.org/10.1097/01.ju.0000067625.45000.9e

5. Gurinder Singh ASS. Giant Peno-scrotal elephantiasis. International Journal of Clinical Cases and Investigations 2011; 3(1): 16-20.

6. Modolin M, Mitre Al, da Silva JC, Cintra W, Quagliano AP, Arap S, et al. Surgical treatment of lymphedema of the penis and scrotum. Clinics 2006; 61(4): 289-94. https://doi.org/10.1590/\$1807-59322006000400003

7. Sauer PF, Bueschen AJ, Vasconez LO. Lymphedema of the penis and scrotum. Clinics in plastic surgery. 1988; 15(3): 507-11.

8. Brotherhood HL, Metcalfe M, Goldenberg L, Pommerville P, Bowman C, Naysmith D. A surgical challenge: Idiopathic scrotal elephantiasis. Canadian Urological Association journal = Journal de l'Association des urologues du Canada 2014; 8(7-8): E500-7. https://doi.org/10.5489/cuaj.1739
9. Stokes THMF, Keith E. BA¥; Silverstein, Ari D. MDt; Weizer, Alon Z. MDt; Donatucci, Craig F. MDt; Anderson, Everett E. MDt; Erdmann, Detlev MD, PhD*. Use of Negative-Pressure Dressings and Split-Thickness Skin Grafts Following Penile Shaft Reduction and Reduction Scrotoplasty in the Management of Penoscrotal Elephantiasis. Annals of Plastic Surgery 2006; 56(6): 649-653. https://doi.org/10.1097/01.sap.0000202826.61782.c9

10. C K. Lymphoedema of penis and scrotum. Br J Plast Surg 1968; 21: 38t-6.

11. Denzinger $S$, Watzlawek $E$, Burger M, Wieland WF, Otto W. Giant scrotal elephantiasis of inflammatory etiology: a case report. Journal of medical case reports 2007; 1: 23. https://doi.org/10.1186/1752-1947-1-23

12. Cintra Junior W, Modolin ML, Rocha RI, Fernandes TR, Nogueira $A B$, Gemperli R. Results of surgical treatment of massive localized lymphedema in severely obese patients. Revista do Colegio Brasileiro de Cirurgioes 2014; 41(1): 18-22. https://doi.org/10.1590/5010069912014000100005

13. Yosipovitch G, DeVore A, Dawn A. Obesity and the skin: skin physiology and skin manifestations of obesity. Journal of the American Academy of Dermatology. 2007; 56(6): 901-16; quiz 17-20. https://doi.org/10.1016/j.jaad.2006.12.004 